\title{
Structure Elucidation, Relative LC-MS Response and In Vitro Toxicity of Azaspiracids 7-10 Isolated from Mussels (Mytilus edulis)
}

\author{
Kilcoyne Jane ${ }^{1,2,{ }^{*}}$, Twiner Michael $J^{3}$., Mccarron Pearse ${ }^{4}$, Crain Sheila ${ }^{4}$, Giddings Sabrina D. ${ }^{4}$ \\ Foley Barry ${ }^{2}$, Rise Frode ${ }^{5}$, Hess Philipp ${ }^{6}$, Wilkins Alistair L. ${ }^{7}$, Miles Christopher O. ${ }^{7,8}$
}

${ }^{1}$ Marine Institute, Rinville, Oranmore, County Galway, Ireland

${ }^{2}$ School of Chemical and Pharmaceutical Sciences, Dublin Institute of Technology, Kevin Street, Dublin 8 , Ireland

${ }^{3}$ School of Medicine, Wayne State University, Detroit, Michigan 48202, United States

${ }^{4}$ Measurement Science and Standards, Biotoxin Metrology, National Research Council Canada, 1411

Oxford Street, Halifax, Nova Scotia B3H 3Z1, Canada

${ }^{5}$ Department of Chemistry, University of Oslo, N-0315 Oslo, Norway

${ }^{6}$ Ifremer, Laboratoire Phycotoxines, Rue de l'lle d'Yeu, 44311 Nantes, France

${ }^{7}$ Norwegian Veterinary Institute, P.O. Box 750 Sentrum, 0106 Oslo Norway

${ }^{8}$ Department of Pharmaceutical Chemistry, School of Pharmacy, University of Oslo, P.O. Box 1068

Blindern, N-0316 Oslo Norway

* Corresponding author : Jane Kilcoyne, tel. + 35391387376 ;

email address : jane.kilcoyne@marine.ie.

\begin{abstract}
:
Azaspiracids (AZAs) are marine biotoxins produced by dinoflagellates that can accumulate in shellfish, which if consumed can lead to poisoning events. AZA7-10, 7-10, were isolated from shellfish and their structures, previously proposed on the basis of only LC-MS/MS data, were confirmed by NMR spectroscopy. Purified AZA4-6, 4-6, and 7-10 were accurately quantitated by qNMR and used to assay cytotoxicity with Jurkat T lymphocyte cells for the first time. LC-MS(MS) molar response studies performed using isocratic and gradient elution in both selected ion monitoring and selected reaction monitoring modes showed that responses for the analogues ranged from 0.3 to 1.2 relative to AZA1, 1 . All AZA analogues tested were cytotoxic to Jurkat T lymphocyte cells in a time- and concentrationdependent manner; however, there were distinct differences in their EC50 values, with the potencies for each analogue being: $A Z A 6>A Z A 8>A Z A 1>A Z A 4 \approx A Z A 9>A Z A 5 \approx A Z A 10$. This data contributes to the understanding of the structure-activity relationships of $A Z A$ s.
\end{abstract}




\section{Graphical abstract}

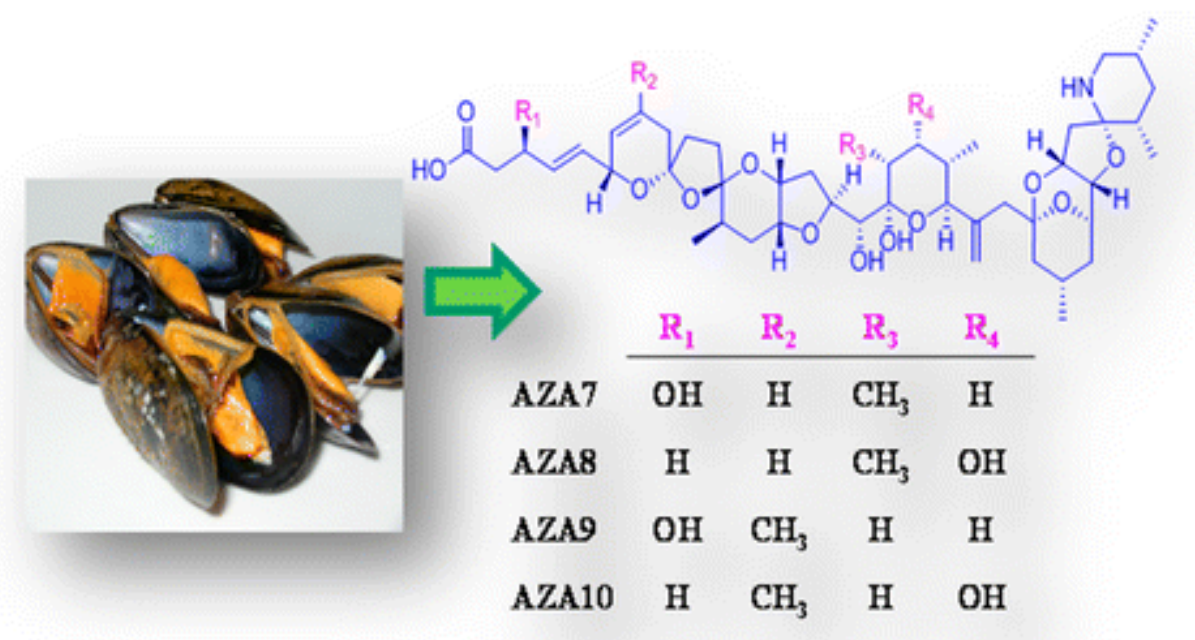

Keywords : azaspiracid ; structure confirmation ; LC-MS molar response ; NMR; mass spectrometry ; purification ; Jurkat T ; toxicity 


\section{Introduction}

The consumption of shellfish contaminated with azaspiracids (AZAs) leads to the syndrome azaspiracid poisoning (AZP). ${ }^{1}$ Poisoning incidents associated with this toxin group have been reported in Europe and in the USA. ${ }^{2,3}$ In these cases, the source of the implicated shellfish was Ireland, where the levels and number of AZA occurrences have been most problematic. ${ }^{4}$ AZAs have been reported to produce neurotoxin-like" symptoms via intraperitoneal injection in mice, with death in 20-90 min. ${ }^{5}$ Oral administration was found to produce clinical disease that was dose- and timedependant, in addition to damaging the intestinal organs. ${ }^{6-9}$ AZA1, 1, (Figure 1) is a $\mathrm{K}^{+}$channel blocker, ${ }^{10}$ and is highly cytotoxic to multiple cell types which undergo atypical apoptosis after exposure. ${ }^{11}$

AZAs were first identified in the late 1990s and since then more than 30 analogues have been observed in shellfish, ${ }^{12}$ phytoplankton, ${ }^{13-15}$ crabs $^{16}$ and a marine sponge. ${ }^{17}$ Only 1, AZA2, 2, and AZA3, 3, (Figure 1) are currently regulated in raw shellfish. ${ }^{18}$ Compounds 1 and 2 are produced by the dinoflagellate Azadinium spinosum, ${ }^{13}$ while many of the other analogues are shellfish metabolites. ${ }^{19,20}$ Compounds $1,{ }^{21} \mathbf{2}, 3,{ }^{22}$ AZA4, 4, AZA5, 5, ${ }^{23}$ and AZA6, $6,{ }^{24}$ have been isolated and their structures elucidated through a combination of NMR spectroscopy and chemical reactions. More recently, 37-epi-1 was isolated from shellfish extracts, and found to differ structurally from 1 in respect of the orientation of the methyl group at $\mathrm{C}-37$, and to be 5-fold more toxic than 1 using the Jurkat T lymphocyte cell assay. ${ }^{25}$

LC-MS analysis revealed the presence of hitherto unknown AZAs in the dinoflagellates Amphidoma languida, ${ }^{13}$ Azadinium poporum ${ }^{14}$ and Azadinium spinosum. ${ }^{15}$ The AZAs identified in $A$. spinosum, subsequently named AZA33 and -34 , were found to be the same structurally at the amine end of the molecule (C-21-40) compared to 1, producing the characteristic $\mathrm{m} / \mathrm{z} 362$ fragment during LCMS/MS analysis. ${ }^{15}$ AZAs from A. poporum (AZA36 and -37), on the other hand, differ by the lack of a methyl or methylene group in the I-ring, resulting in an equivalent fragment with $\mathrm{m} / \mathrm{z} 348 .{ }^{9}$ The AZAs (with molecular masses of 815 and $829 \mathrm{Da}$ ) detected in the A. languida also displayed fragment ions with $m / z 348$, suggesting that these compounds also may lack a methyl or methylene group in the I-ring. ${ }^{14}$

In order to protect shellfish consumers, while at the same time avoiding unnecessary closures of shellfish farms, more information is required about the type and toxity of AZAs found in shellfish, and how to quantitate them. Here we describe the isolation of $\mathbf{4}, 5$ and for the first time AZA7, 7, AZA8, 8, AZA9, 9, and AZA10, 10, (Figure 1) from shellfish, with confirmation by NMR of the structures previously postulated based on LC-MS/MS. Relative molar response studies using mass spectrometry were performed following the preparation of reference standards which had concentrations assigned using quantitative NMR (qNMR). The toxicity of 4-10 was assessed using the Jurkat $T$ lymphocyte cell assay and the results used to discern structure-activity relationships (SARs).

\section{Materials and methods}

\subsection{Chemicals.}

All solvents (pesticide analysis grade) were from Labscan (Dublin, Ireland) and Caledon (Georgetown, Ontario, Canada). Distilled $\mathrm{H}_{2} \mathrm{O}$ was further purified using a Barnstead nanopure diamond UV purification system (Thermo Scientific, Waltham, MA). Sodium chloride (99+\%), triethylamine $(99 \%)$, ammonium acetate $(97+\%)$, ammonium formate (reagent grade), formic acid $(>98 \%)$, silica gel $(10-40 \mu \mathrm{m}$, type $\mathrm{H})$, sodium chloride $(99+\%)$, sodium periodate, Trace CERT caffeine and $\mathrm{CD}_{3} \mathrm{OD}$ (100.0 atom-\% D) were from Sigma-Aldrich (Steinheim, Germany). Sephadex LH-20 was from GE Healthcare (Uppsala, Sweden), LiChroprep RP C8 (25-40 $\mu \mathrm{m})$ was from Merck (Darmstadt, Germany), Luna Phenyl-Hexyl (15 $\mu \mathrm{m}$ ) was from Phenomenex (Cheshire, UK), $\mathrm{CD}_{3} \mathrm{OH}$ 
(99.5 atom-\% D) for qNMR was from Cambridge Isotope Laboratories (Tewksbury, MA). AZA certified reference materials (CRMs) were obtained from the National Research Council (Halifax, NS, Canada).

\subsection{Isolation and Purification of 4-10.}

The isolation procedure was described previously. ${ }^{24}$ Final purification of AZAs was achieved by semi-preparative chromatography on a model 1200 instrument (Agilent Technologies, Santa Clara, CA) with photodiode array (PDA) detection $(210 \mathrm{~nm})$ using a $250 \mathrm{~mm} \times 4.6 \mathrm{~mm}$ i.d., $5 \mu \mathrm{m}$, Cosmosil C18 column (Nacalai tesque, Kyoto, Japan) eluted with $\mathrm{CH}_{3} \mathrm{CN} / \mathrm{H}_{2} \mathrm{O}(1: 1$, plus $2 \mathrm{mM}$ ammonium acetate) at $1 \mathrm{~mL} / \mathrm{min}$. The column temperature was $30{ }^{\circ} \mathrm{C}$. Due to the presence of co-eluting compounds two additional semi-preparative steps using $\mathrm{CH}_{3} \mathrm{CN} / \mathrm{H}_{2} \mathrm{O}(0.8: 1$, plus $2 \mathrm{mM}$ ammonium acetate) were required to attain sufficient purity for NMR. Purified AZAs were recovered by diluting the fractions with $\mathrm{H}_{2} \mathrm{O}$ (to $20 \% \mathrm{CH}_{3} \mathrm{CN}$ ), loading on to solid-phase extraction (SPE) cartridges (Oasis $\mathrm{HLB}, 200 \mathrm{mg})$, washing with $\mathrm{MeOH} / \mathrm{H}_{2} \mathrm{O}(1: 9,10 \mathrm{~mL})$ to remove the buffer, and eluting with $\mathrm{MeOH} / \mathrm{H}_{2} \mathrm{O}(9: 1,20 \mathrm{~mL})$. Removal of solvent by evaporation in vacuo afforded purified AZAs as white solids.

Accurate reference standards of the purified AZAs were prepared by diluting the qNMR stock solutions in high purity degassed $\mathrm{MeOH}$. The concentrations of the working solutions were $\sim 1 \mu \mathrm{M}$ for all analogues.

\subsection{Periodate Cleavage.}

Dilutions ( $100 \mathrm{ng} / \mathrm{mL}$ ) of purified 1-10 in $\mathrm{MeOH}$ were used. To $100 \mu \mathrm{L}$ of each sample was added $50 \mu \mathrm{L}$ of $0.2 \mathrm{M}$ sodium periodate solution, and the reactions analyzed immediately by LC-MS (method B) including traces at $\mathrm{m} / \mathrm{z} 448.4$ (for the 7 oxidation product), $\mathrm{m} / \mathrm{z} 464.4$ (for the 8 oxidation product), $\mathrm{m} / \mathrm{z} 434.4$ (for the 9 oxidation product) and at $\mathrm{m} / \mathrm{z} 450.4$ (for the 10 oxidation product).

\subsection{Mass Spectrometry.}

Method A. Recoveries were determined by quantitative analysis of fractions on a model 2695 LC instrument (Waters, Manchester, UK) coupled to a triple-stage quadrupole (TSQ) Ultima instrument (Micromass, Manchester, UK) operated in selected reaction monitoring (SRM) mode for the following transitions: $\mathrm{m} / \mathrm{z} \quad 842.5 \rightarrow 824.5 / 362.3 \quad$ (1 and 6); $\mathrm{m} / \mathrm{z} \quad 856.5 \rightarrow 838.5 / 362.3 \quad$ (2); $\mathrm{m} / \mathrm{z}$ $828.5 \rightarrow 810.5 / 362.3(3) ; \mathrm{m} / \mathrm{z} 844.5 \rightarrow 826.5 / 362.3(4$ and 5 ) and $\mathrm{m} / \mathrm{z} 858.5 \rightarrow 840.5 / 362.3$ (7-10). The cone voltage was $60 \mathrm{~V}$, collision energy was $50 \mathrm{~V}$, the cone and desolvation gas flows were set at 100 and $800 \mathrm{~L} / \mathrm{h}$, respectively, and the source temperature was $150{ }^{\circ} \mathrm{C}$.

Binary gradient elution was used, with phase $A$ consisting of $\mathrm{H}_{2} \mathrm{O}$ and phase $\mathrm{B}$ of $\mathrm{CH}_{3} \mathrm{CN}(95 \%)$ in $\mathrm{H}_{2} \mathrm{O}$ (both containing $2 \mathrm{mM}$ ammonium formate and $50 \mathrm{mM}$ formic acid). The column used was a 50 $\mathrm{mm} \times 2.1 \mathrm{~mm}$ i.d., $3 \mu \mathrm{m}$, Hypersil BDS C8 column with a $10 \mathrm{~mm} \times 2.1 \mathrm{~mm}$ i.d. guard column of the same stationary phase (Thermo Scientific, Waltham, MA). The gradient was from $30 \%$ to $90 \%$ B over $8 \mathrm{~min}$ at $0.25 \mathrm{~mL} / \mathrm{min}$, held for $5 \mathrm{~min}$, then held at $100 \% \mathrm{~B}$ at $0.4 \mathrm{~mL} / \mathrm{min}$ for $5 \mathrm{~min}$, before returning to the initial for equilibration. The injection volume was $5 \mu \mathrm{L}$ and the column and sample temperatures were $25^{\circ} \mathrm{C}$ and $6^{\circ} \mathrm{C}$, respectively.

Method B. Structures and purities were assessed on a model 2795 LC instrument (Waters, Manchester, UK) coupled to a quadrapole time-of-flight (QToF) Ultima instrument (Micromass, Manchester, UK) by running MS scans $(\mathrm{m} / \mathrm{z} 100-1000)$ using the same chromatographic conditions as method $A$. The possible presence of other AZA contaminants was determined by performing product ion scans, where the precursor ions were selected and then fragmented, for all the known AZA analogues. 
Method C. For a relative molar response study analysis was performed on a model 1200 LC instrument (Agilent Technologies, Santa Clara, CA) connected to a model API4000 QTRAP mass spectrometer (AB Sciex, Framingham, MA) equipped with a Turbospray ionization source. The MS was operated in positive ion mode and SRM transitions were as follows: $\mathrm{m} / \mathrm{z}$ $842.5 \rightarrow 824.5 / 672.5 / 462.3 / 362.3 \quad(1) ; \quad \mathrm{m} / \mathrm{z} \quad 844.5 \rightarrow 826.5 / 658.5 / 362.3 \quad(4) ; \quad \mathrm{m} / \mathrm{z}$ $844.5 \rightarrow 826.5 / 674.5 / 362.3(5) ; \mathrm{m} / \mathrm{z} \quad 842.5 \rightarrow 824.5 / 658.5 / 362.3(6) ; \mathrm{m} / \mathrm{z} \quad 858.5 \rightarrow 840.5 / 672.5 / 362.3$ (7); $\quad \mathrm{m} / \mathrm{z} \quad 858.5 \rightarrow 840.5 / 688.5 / 362.3 \quad(8) ; \quad \mathrm{m} / \mathrm{z} \quad 858.5 \rightarrow 840.5 / 658.5 / 362.3 \quad$ (9) and $\mathrm{m} / \mathrm{z}$ $858.5 \rightarrow 840.5 / 674.5 / 362.3(10)$. For selected ion monitoring (SIM) experiments $\mathrm{m} / \mathrm{z} 842.5$ (1 and 6 ), 844.5 (4 and 5) and 858.5 (7-10) were analysed. Typical parameters were $5500 \mathrm{~V}$ electrospray voltage, $400{ }^{\circ} \mathrm{C}$ source temperature, $70 \mathrm{~V}$ declustering potential and collision energies of 45 to $70 \mathrm{~V}$ (where applicable). Method C (i) used gradient elution with the same acidic mobile phase as method A. The column used was a $2.1 \mathrm{~mm} \times 50 \mathrm{~mm}$ i.d., $2.5 \mu \mathrm{m}$ Luna C18(2) HST column (Phenomenex, Cheshire, UK). The gradient was from 25 to $100 \%$ B over $5 \mathrm{~min}$ at $300 \mu \mathrm{L} / \mathrm{min}$ and held at $100 \% \mathrm{~B}$ for $2 \mathrm{~min}$, before re-equilibration for the next run. The injection volume was 1-5 $\mu \mathrm{L}$ and the column and sample temperatures were $25^{\circ} \mathrm{C}$ and $6{ }^{\circ} \mathrm{C}$, respectively. Method $\mathrm{C}$ (ii) used isocratic elution with the acidic mobile phase on the same Luna column, with $60 \% \mathrm{~B}$ at $300 \mu \mathrm{L} / \mathrm{min}$.

Method $D$. For separation of the 37 -epimers ${ }^{25}$ a neutral gradient elution was used. ${ }^{27}$ The column used was a $2.1 \mathrm{~mm} \times 50 \mathrm{~mm}$ i.d., $2.5 \mu \mathrm{m}$, Luna C18(2) HST column (Phenomenx, Cheshire, UK), operated at $15{ }^{\circ} \mathrm{C}$, injecting $1-5 \mu \mathrm{L}$ samples. A binary mobile phase of $\mathrm{H}_{2} \mathrm{O}(\mathrm{A})$ and $\mathrm{CH}_{3} \mathrm{CN}(95 \%)$ in $\mathrm{H}_{2} \mathrm{O}(\mathrm{B})$, each containing $5 \mathrm{mM}$ ammonium acetate $(\mathrm{pH} 6.8)$, was used with a linear gradient from 25 to $100 \%$ B over $5 \mathrm{~min}$ at $350 \mu \mathrm{L} / \mathrm{min}$ and held at $100 \% \mathrm{~B}$ for $2 \mathrm{~min}$, before re-equilibration for the next run.

Method E. Accurate mass measurements were performed on an Acquity UPLC instrument coupled to a Xevo G2-S QToF (Waters, Manchester, UK) operated in $\mathrm{MS}^{e}$ mode, scanning from $\mathrm{m} / \mathrm{z}$ 100-1200 and using leucine enkephalin as the reference compound. The cone voltage was $40 \mathrm{~V}$, collision energy was $50 \mathrm{~V}$, the cone and desolvation gas flows were set at 100 and $1000 \mathrm{~L} / \mathrm{h}$, respectively, and the source temperature was $120^{\circ} \mathrm{C}$.

The column used was a $50 \mathrm{~mm} \times 2.1 \mathrm{~mm}$ i.d., $1.7 \mu \mathrm{m}$, Acquity UPLC BEH C18 (Waters, Wexford, Ireland), using the same mobile phase described in method A. The gradient was from 30 to $90 \% \mathrm{~B}$ over $5 \mathrm{~min}$ at $0.3 \mathrm{~mL} / \mathrm{min}$, held for $0.5 \mathrm{~min}$, and returned to the initial conditions and held for $1 \mathrm{~min}$ to equilibrate the system. The injection volume was $2 \mu \mathrm{L}$ and the column and sample temperatures were $25^{\circ} \mathrm{C}$ and $6{ }^{\circ} \mathrm{C}$, respectively.

\subsection{NMR Spectroscopy.}

NMR experiments for structure elucidation were run using Avance I and Avance II $600 \mathrm{MHz}$ spectrometers (Bruker, Fällanden, Switzerland) equipped with $\mathrm{TCl}$ cryoprobes and Z-gradient coils, at $30{ }^{\circ} \mathrm{C}$, while a Bruker DRX-500 spectrometer (Milton, Ontario, Canada) with a TXI probe and Zgradient coils at $20^{\circ} \mathrm{C}$ was used for qNMR. Structures were determined by analysis of ${ }^{1} \mathrm{H}$, COSY, TOCSY, NOESY, ROESY, HSQC and HMBC, ${ }^{13} \mathrm{C}$ and DEPT135 NMR spectra. Samples of 4-10 $\sim \sim$ $0.1 \mathrm{mg}$ ) were dissolved in $\sim 0.5 \mathrm{~mL} \mathrm{CD} \mathrm{CD}_{3} \mathrm{OD}$ at $30{ }^{\circ} \mathrm{C}$, and chemicals shifts were referenced to internal $\mathrm{CHD}_{2} \mathrm{OD}(3.31 \mathrm{ppm})$ or $\mathrm{CD}_{3} \mathrm{OD}(49.0 \mathrm{ppm})$. Single- or double-frequency pre-saturation of solvent resonances was performed using continuous wave and/or excitation sculpting, as required. Quantitation of $\mathbf{1}$ and 4-10 was performed on aliquots of the purified compounds by dissolving in $\mathrm{CD}_{3} \mathrm{OH}$. The samples were run against external standards of caffeine dissolved in $\mathrm{H}_{2} \mathrm{O}(4.1 \mathrm{mM})$ as described previously for AZA CRMs. ${ }^{28}$

\subsection{Toxicology.}

Cell Culturing. Human Jurkat E6-1 T lymphocyte cells (American Type Culture Collection TIB-152, Manassas, VA) were grown as described by Twiner et al. ${ }^{29}$ Briefly, cells were grown in RPMI medium (Invitrogen, Carlsbad, CA) supplemented with 10\% (v/v) fetal bovine serum (Invitrogen, Carlsbad, CA) and maintained in a humidified incubator with $5 \% \mathrm{CO}_{2}$ in air at $37{ }^{\circ} \mathrm{C}$. Cells were 
subcultured with fresh medium at an inoculum ratio of $1: 4$ every 3 to 4 days by transferring $2.5 \mathrm{~mL}$ of cells to $7.5 \mathrm{~mL}$ of fresh supplemented medium in $75 \mathrm{~cm}^{2}$ screw cap culture flasks.

Cytotoxicity Assay. To determine the effect of 1, 4-6 and 8-10 on cellular toxicity, Jurkat T lymphocyte cells were continuously exposed to toxins and viability determined. The non-adherent human cell line Jurkat T lymphocyte was grown in RPMI medium supplemented with $10 \%(\mathrm{v} / \mathrm{v})$ fetal bovine serum. Cells were maintained in humidified $5 \% \mathrm{CO}_{2}$ in air at $37{ }^{\circ} \mathrm{C}$ and subcultured with fresh medium at an inoculum ratio of $1: 10$ every 5 to 7 days by transferring $1 \mathrm{~mL}$ of cells to $9 \mathrm{~mL}$ of fresh supplemented medium in $75 \mathrm{~cm}^{2}$ screw cap culture flasks. Cells were seeded in a volume of $100 \mu \mathrm{L}$ of the supplemented medium at a density of 35,000 cells per well in black, sterile, 96-well culture plates for $24 \mathrm{~h}$ to allow for recovery and settling. Each AZA was added at a single concentration $(10 \mathrm{nM})$ for 24,48 , or $72 \mathrm{~h}$ of continuous exposure prior to assessment of cytotoxicity. Parallel controls of equivalent amounts of $\mathrm{MeOH} / \mathrm{phosphate}$ buffered saline were used to normalize the viability data for each treatment. Cellular viability/cytotoxicity was assessed using the 3-(4,5dimethylthiazol-2-yl)-5-(3-carboxymethoxyphenyl)-2-(4-sulfophenyl)-2H-tetrazolium (MTS) assay (Promega Biosciences, Sunnyvale, CA). Like other tetrazolium-based assays, MTS in the presence of an electron coupling reagent (phenazine methosulfate; PMS) measures cellular viability by determining the activity of mitochondrial dehydrogenase. ${ }^{30}$ As a substrate for dehydrogenases, MTS becomes reduced into a soluble, purple dye that can be quantitated colourimetrically to determine the relative level of cellular viability/cytotoxicity per well. Following exposure of the cells to the AZA analogues for the specified period of time, each well received $10 \mu \mathrm{L}$ of a PMS/MTS $(1: 20)$ solution. Cells were incubated for $4 \mathrm{~h}$, after which absorbance readings at $485 \mathrm{~nm}$ were obtained using a FluoStar microplate reader (BMG Lab Technologies, Cary, NC). Data are presented as means \pm SE ( $n=3$ to 5 ). In addition, each cytotoxicity experiment was performed using duplicate wells. Cytotoxicity data were blank-corrected and normalized to the control ( $\%$ viability) and plotted using GraphPad Prism (ver. 5.0c).

\section{Results and discussion}

The isolation of 6 has previously been described. ${ }^{24}$ Hydroxylated analogs 4,5 and 7-10 are less lipophilic than 1-3 and 6, and therefore eluted earlier ${ }^{12}$ and were more difficult to separate from the other contaminants in the sample. In the initial semi preparative HPLC step, $\mathbf{4}$ and $\mathbf{5}$ and $\mathbf{7 - 1 0}$ were collected as two separate fractions. Individual analogues were separated in a second chromatographic step, while a third was required to achieve sufficient purity for NMR spectroscopy. The amounts purified ranged from 100-200 $\mu \mathrm{g}$. Each analogue also contained its corresponding 37-epimer $(\sim 2-15 \%)$ as recently reported. ${ }^{25}$ Sufficient purity for the cytotoxicity assay was achieved for all AZAs except for 7 (purity $\sim 63 \%$ ), which was contaminated with $\mathbf{5}$ and another hitherto unreported AZA ( 20\%) with a molecular mass of $825 \mathrm{Da}$, which was also detected in the initial hepatopancreas (HP) extract. Compounds 4, 5, 6, 8 and 10 all had purities (including the 37epimers) of $>95 \%$, while 9 had a purity of $89 \%$.

\subsection{Structure Determination.}

The AZAs isolated in this study showed typical AZA mass spectral fragmentation patterns, namely a protonated molecular ion, retro Diels-Alder (RDA) and $\mathrm{m} / \mathrm{z} 362$ fragments (Figure 1), all of which appeared in clusters, indicative of several $\mathrm{H}_{2} \mathrm{O}$ losses. NMR structure elucidation was done using 1D and 2D-homonuclear ${ }^{1} \mathrm{H},{ }^{13} \mathrm{C}$ and heteronuclear ${ }^{1} \mathrm{H}\left\{{ }^{13} \mathrm{C}\right\}$ spectroscopy to assign the ${ }^{1} \mathrm{H}$ and ${ }^{13} \mathrm{C}$ resonances, the chemical shifts of which were then compared with the published ${ }^{1} \mathrm{H}$ (for 1-6) and ${ }^{13} \mathrm{C}$ NMR (for 1-3 and 6) data for 1-6. ${ }^{21-24}$ The majority of chemical shifts in Table 1 are from 1DNMR spectra but some chemical shifts were from 2D-spectra where necessary due to weak or overlapping signals. All samples inevitably contained low percentages of the corresponding 37epimer, ${ }^{25}$ but this did not interfere with NMR analyses and is not discussed further. Other minor AZAs were sometimes present as contaminants in the samples but not at levels sufficient to prevent spectrometric analysis. 
AZA4 (4) and AZA5 (5). Structure assignments for 4 have been published based on ${ }^{1} \mathrm{H}$ NMR and fast atom bombardment $(F A B) M S^{23}$ which was considered to show C-3 hydroxylation. This study confirmed those findings. In addition to the expected fragments the MS spectra showed a molecular ion cluster $\left(\mathrm{m} / z\right.$ 782.5) suggesting a loss of $\mathrm{CO}_{2}$ followed by several $\mathrm{H}_{2} \mathrm{O}$ losses, that is indicative of C-3 hydroxylation. NMR spectroscopic analysis also demonstrated that 4 is 3 -hydroxylated. We also determined ${ }^{13} \mathrm{C}$ NMR assignments for 4 (Table 1). Although it is not possible to determine the configuration at C-3 from ROESY correlations or coupling constants, $\mathbf{4}$ has been shown to be $3 R$ hydroxyazaspiracid-3 by degradation reactions and synthesis of the degradation products. ${ }^{21}{ }^{1} \mathrm{H}$ NMR assignments for 4 closely paralleled those of Ofuji et al. ${ }^{23}$ apart from variations ${ }^{25}$ attributable to the degree of protonation on the amino group and to the reversal of the resonances for $\mathrm{H}-7$ and $\mathrm{H}-9$ due to the revised position of the double bond in the A-ring. ${ }^{24,31,32}$ The ${ }^{13} \mathrm{C}$ and ${ }^{1} \mathrm{H}$ chemical shifts for the 22-positions of $\mathbf{4}$ were markedly different to those reported recently for $\mathbf{6}$ (39.0, and $2.13(2 \mathrm{H}) \mathrm{ppm}) .^{24}$ However, examination of the original NMR data ${ }^{24}$ for $\mathbf{6}$ indicates that these signals resonate at $31.5 \mathrm{ppm}$ and at 1.50 and $2.10 \mathrm{ppm}$, in accord with the published NMR data for $3{ }^{22}$ as well as that presented here for 4 .

The MS/MS spectrum of 5 showed a fragment peak at $\mathrm{m} / \mathrm{z} 408$ that is indicative of C-23 hydroxylation. ${ }^{33}$ As with 4 the ${ }^{1} \mathrm{H}$ NMR assignments (Table 1 ) for 5 closely paralleled those of Ofuji et al. ${ }^{23}$ Analyses of the ${ }^{1} \mathrm{H}$ NMR data which we recorded for $\mathbf{5}$ confirmed the presence of a hydroxyl group at $\mathrm{C}-23$ and showed that $\mathrm{H}-23(3.93 \mathrm{ppm}, \sim \mathrm{q}, J=2.7 \mathrm{~Hz})$ was equatorially oriented towards the upper $(\beta)$ face of the $\mathrm{C}-21-\mathrm{C}-25$ ring (Figure 2 ) and that the 23-hydroxyl group was therefore axially inclined towards the lower $(\alpha)$ face of this ring.

$A Z A 7(7)$ and $A Z A 9$ (9). Analogously to 4, the MS, MS/MS, periodate cleavage and NMR data showed C-3 hydroxylation (Table 1, Figure 3).

$A Z A 8(8)$ and $A Z A 10$ (10). Analogously to 5, the MS, MS/MS, periodate cleavage and NMR data showed C-23 hydroxylation (Table 1, Figure 2, Figure 3).

Examination of the assignments within Table 1, and comparison with NMR assignments for 1-3 $3^{21,22}$ and $6^{24}$ obtained under the same conditions and calibrated identically, reveals diagnostic effects on chemical shifts arising from the hydroxylations and methylations of the AZA skeleton. Hydroxylation at $\mathrm{C}-3$ leads not only to marked changes in the $\mathrm{C}-3$ and $\mathrm{H}-3$ resonances, but also to significant changes $\left(\geq \sim 1 \mathrm{ppm}\right.$ for ${ }^{13} \mathrm{C}, \geq \sim 0.05 \mathrm{ppm}$ for ${ }^{1} \mathrm{H}$ ) to the nearby $\mathrm{C}-2, \mathrm{C}-4, \mathrm{H}-2, \mathrm{H}-5$ and $\mathrm{H}-6$ resonances. Similarly, hydroxylation at C-23 leads to consistent alterations in the chemical shifts of $\mathrm{C}-22-\mathrm{C}-25$ and $\mathrm{H}-22-\mathrm{H}-25$ as well as the appended 22- (if present) and 24-methyl groups in the Ering. Addition of a methyl group at $\mathrm{C}-8$ also results in characteristic changes to the $\mathrm{C}-7-\mathrm{C}-9$ and $\mathrm{H}$ 6-H-9 resonances. Similarly, the presence or absence of a 22-methyl has a pronounced effect on the chemical shifts of $\mathrm{C}-22-\mathrm{C}-24$ and $\mathrm{H}-22$ and $\mathrm{H}-23$.

The previously reported effect attributed to the state of ionization of the amino group ${ }^{23}$ is evident in Table 1, leading to systematic changes to most of the resonances of rings $\mathrm{F}-\mathrm{I}(\mathrm{C}-35, \mathrm{C}-37-\mathrm{C}-40, \mathrm{H}-$ $29, \mathrm{H}-31-\mathrm{H}-40$, and the 37- and 39-methyl groups). This effect is also observable on a number of remote resonances $(\mathrm{H}-18, \mathrm{H}-19$ and the olefinic methylene at $\mathrm{C}-26)$, consistent with molecular modelling and ROESY correlations indicating the ring systems $\mathrm{F}-\mathrm{I}$ to be folded over in such a way that the amino group is near $\mathrm{H}-19$, so that $\mathbf{1}, 2,{ }^{23} \mathbf{4}, \mathbf{5}$ and $\mathbf{7 - 1 0}$ all showed ROESY correlations between $\mathrm{H}-19$ and $\mathrm{H}-40_{\text {eq. }}$. Knowledge of these consistent substituent effects on the AZA skeleton will be helpful during NMR structure analysis of other AZA congeners and metabolites.

Further structural evidence was obtained by treatment with periodate which cleaves whenever a diol moiety is present. LC-MS analysis showed that treatment of 7-10 with periodate yielded C-20-C21-cleavage products at $\mathrm{m} / \mathrm{z} 448.4$ for 7 (with the same retention time as the cleavage products from 1 and 2), $\mathrm{m} / z 464.4$ for $\mathbf{8}, \mathrm{m} / \mathrm{z} 434.4$ for $\mathbf{9}$ (same retention time as products from $\mathbf{3}$ and $\mathbf{6}$ ) and $\mathrm{m} / \mathrm{z} 450.4$ for 10 (same retention time as the product from 5) (Figure 3). Because the structures of 
1-6 are well established, ${ }^{21-24}$ these results confirm the C-20-C-40 substructures of 7, 9 and 10 that were determined by NMR spectroscopy shown (Figure 1).

As 4, 5, 7, 8, 9 and 10 are produced in mussels by enzymatic oxidations and decarboxylations of 1 and 2 biosynthesized by dinoflagellates, it follows that their absolute configurations are as shown in Figure 1. Analogs $\mathbf{4}, \mathbf{5}, \mathbf{7}$ and $\mathbf{8}$ are proposed to be bioconversion products of $\mathbf{1}$, while $\mathbf{9}$ and $\mathbf{1 0}$ appear to be bioconversion products of $2 . .^{20,34}$

\subsection{Relative Molar Response Study.}

For the AZAs studied, differences in response factors were less significant in SIM mode under isocratic conditions (Table 2). In LC-MS/MS, the mobile phase composition can influence the ionization efficiency, therefore analysis under isocratic conditions produces more accurate results. The response factor for $\mathbf{6}$ was very similar to that of $\mathbf{1}$. All the hydroxylated AZAs gave lower response factors, with 7, 9 and 10 being the lowest at $\sim 0.5$ (Figure 4 ).

The data shows that the SRM transition selected for analysis of all the AZAs, including 6, can significantly impact quantitation when using 1 as a calibration standard (Table 2). The $\mathrm{H}_{2} \mathrm{O}$ loss transition for $\mathbf{6}$ was similar to that of $\mathbf{1}$, however the RDA cleavage of the A-ring resulted in significantly higher response factors under both isocratic and gradient conditions. For all the other AZAs, the differences in SRM mode were even greater. The results suggest that, in the absence of standards for the hydroxylated analogues, quantitation will be more accurate in SIM mode under isocratic conditions and that the concentration of hydroxylated AZAs may be significantly underestimated when AZA1 alone is used for calibration (Table 2).

\subsection{Toxicology.}

All available AZA analogues tested were cytotoxic to Jurkat T lymphocyte cells in a time- and concentration-dependent manner (Figure 5). However, there were distinct differences in the relative potencies of each analogue as revealed by their $\mathrm{EC}_{50}$ values (Table 3 ). The range of $\mathrm{EC}_{50}$ values for the eight analogues tested in this study were 0.1 to $3.1 \mathrm{nM}$, a 31 -fold range. Based on the $\mathrm{EC}_{50}$ values, the relative potencies were: $\mathbf{2}^{35}>\mathbf{6}>\mathbf{8} \approx \mathbf{3}^{35}>\mathbf{1}>\mathbf{4} \approx \mathbf{5} \approx \mathbf{9}>\mathbf{1 0}$. Impurities in 7 prevented it from being subjected to the Jurkat cell assay.

In the present study, the AZAs tested represented differing sites of methylation, and hydroxylation. Collectively, SAR analysis using these data and published data for 2 and $3^{35}$ suggest that AZA potency was somewhat increased by methylation at C-8 and/or C-22 (i.e., 2, 6) whereas potency was reduced somewhat by hydroxylation at C3 and/or C23 (i.e., 4, 5) (Table 3, Figure 5). These findings allow us to speculate on the relative potencies of other analogues such as AZA12 (predicted to have relatively higher potency) and AZA13 (predicted to have relatively lower potency) based on their structures. Interestingly, reduced potencies of 4 and 5 relative to 1 in the Jurkat cell assay are the same as those determined by intraperitoneal injection in mice. ${ }^{23}$ The utility of this in vitro cytotoxicity assay for relative analogue potencies (i.e., TEFs) are further corroborated by previous in vitro and in vivo studies whereby both techniques also clearly demonstrated increased potencies of 2 and 3 relative to 1. ${ }^{21,22,35}$ However, recent in vivo studies (mouse intraperitoneal and mouse oral) showed that 1 is more toxic than 2 (mouse intraperitoneal $\approx$ oral; TEF $=0.6-0.7$ ) and 3 (mouse intraperitoneal $=$ oral; TEF $=0.5) .{ }^{9}$ Furthermore, the toxicity of 6 was determined by mouse intraperitoneal for the first time and was found to be less toxic (TEF $=0.7$ ) than $1 .{ }^{9}$ Although the reason for this discrepancy is unknown at this time, the oral in vivo studies probably have more relevance for protecting shellfish consumers. However, oral dosing experiments are difficult to perform due to the high mass of toxins needed. Hence, further studies should be conducted to isolate more of the minor analogues to conclusively clarify their toxicological importance.

In summary, compounds 4-10 were purified from shellfish, with the structures of 7-10 being elucidated for the first time by NMR, which confirmed the previously postulated structures based on 
LC-MS/MS studies. qNMR was performed on all purified samples and subsequent LC-MS(MS) relative molar response factors and cytotoxicity were determined. Differences in the molar responses relative to 1 were observed, particularly for the hydroxylated analogues (up to 3-fold). The differences were least significant when analysing in SIM mode under isocratic conditions. Combining all the cytotoxicity data published to date for AZAs using the Jurkat $T$ lymphocyte cell assay, the order of potencies are: $\mathbf{2}>\mathbf{6} \approx \mathrm{AZA} 34^{15} \approx 37-$ epi-1 ${ }^{25}>\mathbf{8} \approx \mathbf{3}>\mathbf{1}>\mathbf{4} \approx \mathbf{9}>\mathbf{5} \approx \mathbf{1 0}>$ AZA33. ${ }^{15}$

\section{Associated content}

\section{Supporting Information}

Mass spectrum of AZA analogue with $\mathrm{m} / \mathrm{z}$ of $826 \mathrm{Da}$; mass spectra of 4, 5 and 7-10; table of isolated compounds and their purities; NMR spectra of 4,5 and $7-10$. This material is available free of charge via the Internet at http://pubsacs.org.

\section{Funding}

This project (PBA/AF/08/001(01) was carried out under the Sea Change strategy with the support of the Marine Institute and the Marine Research Sub-Programme of the National Development Plan 2007-2013, co-financed under the European Regional Development Fund and supported in part by a Marie Curie International Incoming Fellowship (to C.O.M.) within the seventh European Community Framework Programme (FP7/2007-2013) under grant agreement no. 221117.

\section{Notes}

The authors declare no competing financial interest.

\section{Acknowledgement}

We thank the biotoxin chemistry team at the Marine Institute, Galway, in particular, O. Finch for her assistance in the laboratory. We also thank I. Burton at the National Research Council of Canada for providing original NMR data for AZA6.

\section{References}

(1) Twiner, M. J.; Rehmann, N.; Hess, P.; Doucette, G. J. Azaspiracid shellfish poisoning: a review on the chemistry, ecology, and toxicology with an emphasis on human health impacts. Mar. Drugs, 2008, 6, 39-72.

(2) Furey, A.; O'Doherty, S.; O'Callaghan, K.; Lehane, M.; James, K. Azaspiracid poisoning (AZP) toxins in shellfish: toxicological and health considerations. Toxicon, 2010, 56, 173-190.

(3) Klontz, K. C.; Abraham, A.; Plakas, S. M.; Dickey, R. W. Mussel-associated azaspiracid intoxication in the United States. Ann. Intern. Med. 2009, 150, 361.

(4) Marine Insitute shellfish safety database. http://www.marine.ie/home/publicationsdata/data/Habs+Search+Database/HabsSearch.htm. Accessed 6 March, 2015.

(5) McMahon, T., and Silke, J. Winter toxicity of unknown aetiology in mussels. Harmful Algae News, 1996, 14.

(6) Aune, T.; Espenes, A.; Aasen, J. A. B.; Quilliam, M. A.; Hess, P.; Larsen, S. Study of possible combined toxic effects of azaspiracid-1 and okadaic acid in mice via the oral route. Toxicon, 2012, 60, 895-906.

(7) Ito, E.; Satake, M.; Ofuji, K.; Higashi, M.; Harigaya, K.; McMahon, T.; Yasumoto, T. Chronic effects in mice caused by the oral administration of sublethal doses of azaspiracid, a new marine toxin isolated from mussels. Toxicon, 2002, 40, 193-203. 
(8) Aasen, J. A. B.; Espenes, A.; Hess, P.; Aune, T. Sub-lethal dosing of azaspiracid-1 in female NMRI mice. Toxicon, 2010, 56, 1419-1425.

(9) Kilcoyne, J.; Jauffrais, T.; Twiner, M.; Doucette, G.; Aasen Bunæs, J. A.; Sosa, S.; Krock, B.; Séchet, V.; Nulty, C.; Salas, R.; Clarke, D.; Geraghty, J.; Duffy, C.; Foley, B.; John, U.; Quilliam, M. A.; McCarron, P.; Miles, C. O.; Silke, J.; Cembella, A.; Tillmann, U.; Hess, P. Azaspiracids - toxicological evaluation, test methods and identifcation of the source organisms (ASTOX II), Marine Institute - Marine Research Sub-Programme (NDP 2007-2013) series (http://oar.marine.ie/handle/10793/970), 2014. Accessed 27 March 2015.

(10) Twiner, M. J.; Doucette, G. J.; Rasky, A.; Huang, P. X.; Roth, B. L.; Sanguinetti, M. C. The marine algal toxin azaspiracid is an open state blocker of hERG potassium channels. Chem. Res. Toxicol., 2012, 25, 1975-1984.

(11) Twiner, M. J.; Hanagriff, J. C.; Butler, S.; Madhkoor, A. K.; Doucette, G. J. Induction of apoptosis pathways in several cell lines following exposure to the marine algal toxin azaspiracid-1. Chem. Res. Toxicol. 2012, 25, 1493-1501.

(12) Rehmann, N.; Hess, P.; Quilliam, M. A. Discovery of new analogs of the marine biotoxin azaspiracid in blue mussels (Mytilus edulis) by ultra-performance liquid chromatography/tandem mass spectrometry. Rapid Commun. Mass Spectrom., 2008, 22, 549-558.

(13) Krock, B.; Tillmann, U.; John, U.; Cembella, A. D. Characterization of azaspiracids in plankton size-fractions and isolation of an azaspiracid-producing dinoflagellate from the North Sea. Harmful Algae, 2009, 8, 254-263.

(14) Krock, B.; Tillmann, U.; Voß, D.; Koch, B. P.; Salas, R.; Witt, M.; Potvin, É.; Jeong, H. J. New azaspiracids in Amphidomataceae (Dinophyceae). Toxicon, 2012, 60, 830-839.

(15) Kilcoyne, J.; Nulty, C.; Jauffrais, T.; McCarron, P.; Herve, F.; Wilkins, A. L.; Foley, B.; Rise, F.; Crain, S.; Twiner, M. J.; Hess, P.; Miles, C. O. Isolation, structure elucidation, relative LC-MS response, and in vitro toxicity of azaspiracids from the dinoflagellate Azadinium spinosum. J. Nat. Prod., 2014, 77, 2465-2474.

(16) Torgersen, T.; Bremnes, N. B.; Rundberget, T.; Aune, T. Structural confirmation and occurrence of azaspiracids in Scandinavian brown crabs (Cancer pagurus). Toxicon, 2008, 51, 93-101.

(17) Ueoka, R.; Ito, A.; Izumikawa, M.; Maeda, S.; Takagi, M.; Shin-ya, K.; Yoshida, M.; Van Soest, R. W. M.; Matsunaga, S. Isolation of azaspiracid-2 from a marine sponge Echinoclathria sp. as a potent cytotoxin. Toxicon, 2009, 53, 680-684.

(18) Anon. Commission Regulation (EU) No 15/2011 of 10th January 2011 amending Regulation (EC) No 2074/2005 as regards recognised testing methods for detecting marine biotoxins in live bivalve molluscs. Official Journal of the European Union, 2011, L6, 3-6.

(19) Salas, R.; Tillmann, U.; John, U.; Kilcoyne, J.; Burson, A.; Cantwell, C.; Hess, P.; Jauffrais, T.; Silke, J. The role of Azadinium spinosum (Dinophyceae) in the production of azaspiracid shellfish poisoning in mussels. Harmful Algae, 2011, 10, 774-783.

(20) Jauffrais, T.; Marcaillou, C.; Herrenknecht, C.; Truquet, P.; Séchet, V.; Nicolau, E.; Tillmann, U.; Hess, P. Azaspiracid accumulation, detoxification and biotransformation in blue mussels (Mytilus edulis) experimentally fed Azadinium spinosum. Toxicon, 2012, 60, 582-595.

(21) Satake, M.; Ofuji, K.; Naoki, H.; James, K. J.; Furey, A.; McMahon, T.; Silke, J.; Yasumoto, T. Azaspiracid, a new marine toxin having unique spiro ring assemblies, isolated from Irish mussels, Mytilus edulis. J. Am. Chem. Soc., 1998, 120, 9967-9968.

(22) Ofuji, K.; Satake, M.; McMahon, T.; Silke, J.; James, K. J.; Naoki, H.; Oshima, Y.; Yasumoto, T. Two analogs of azaspiracid isolated from mussels, Mytilus edulis, involved in human intoxications in Ireland. Nat. Toxins, 1999, 7, 99-102.

(23) Ofuji, K.; Satake, M.; McMahon, T.; James, K. J.; Naoki, H.; Oshima, Y.; Yasumoto, T. Structures of azaspiracid analogs, azaspiracid-4 and azaspiracid-5, causative toxins of azaspiracid poisoning in Europe. Biosci. Biotechnol. Biochem., 2001, 65, 740-742.

(24) Kilcoyne, J.; Keogh, A.; Clancy, G.; LeBlanc, P.; Burton, I.; Quilliam, M. A.; Hess, P.; Miles, C. O. Improved isolation procedure for azaspiracids from shellfish, structural elucidation of azaspiracid-6, and stability studies. J. Agric. Food Chem., 2012, 60, 2447-2455. 
(25) Kilcoyne, J.; McCarron, P.; Twiner, M. J.; Nulty, C.; Wilkins, A. L.; Rise, F.; Quilliam, M. A.; Miles, C. O. Epimers of azaspiracids: isolation, structural elucidation, relative LC-MS response, and in vitro toxicity of 37-epi-azaspiracid-1. Chem. Res. Toxicol., 2014, 27, 587-600.

(26) Krock, B.; Tillmann, U.; Witt, M.; Gu, H. Azaspiracid variability of Azadinium poporum (Dinophyceae) from the China Sea. Harmful Algae, 2014, 36, 22-28.

(27) McCarron, P.; Giddings, S. D.; Quilliam, M. A. A mussel tissue certified reference material for multiple phycotoxins. Part 2: liquid chromatography-mass spectrometry, sample extraction and quantitation procedures. Anal. Bioanal. Chem., 2014, 400, 835-846.

(28) Burton, I.; Quilliam, M. A.; Walter, J. A. Quantitative ${ }^{1} \mathrm{H}$ NMR with external standards: use in preparation of calibration solutions for algal toxins and other natural products. Anal. Chem. 2005, 77, 3123-3131.

(29) Twiner, M. J.; Hess, P.; Bottein Dechraoui, M. Y.; McMahon, T.; Samons, M. S.; Satake, M.; Yasumoto, T.; Ramsdell, J. S.; Doucette, G. J. Cytotoxic and cytoskeletal effects of azaspiracid-1 on mammalian cell lines. Toxicon, 2005, 45, 891-900.

(30) Mosmann, T. Rapid colorimetric assay for cellular growth and survival: application to proliferation and cytotoxicity assays. J. Immunol. Methods, 1983, 65, 55-63.

(31) Nicolaou, K. C.; Li, Y. W.; Uesaka, N.; Koftis, T. V.; Vyskocil, S.; Ling, T. T.; Govindasamy, M.; Qian, W.; Bernal, F.; Chen, D. Y. K. Total synthesis of the proposed azaspiracid-1 structure, part 1: construction of the enantiomerically pure $\mathrm{C} 1-\mathrm{C} 20, \mathrm{C} 21-\mathrm{C} 27$, and $\mathrm{C} 28-\mathrm{C} 40$ fragments. Angew. Chem. Int. Edit., 2003, 42, 3643-3648.

(32) Nicolaou, K. C.; Chen, D. Y. K.; Li, Y. W.; Qian, W. Y.; Ling, T. T.; Vyskocil, S.; Koftis, T. V.; Govindasamy, M.; Uesaka, N. Total synthesis of the proposed azaspiracid-1 structure, part 2: coupling of the $\mathrm{C} 1-\mathrm{C} 20, \mathrm{C} 21-\mathrm{C} 27$, and $\mathrm{C} 28-\mathrm{C} 40$ fragments and completion of the synthesis. Angew. Chem. Int. Edit., 2003, 42, 3649-3653.

(33) James, K. J.; Diaz Sierra, M.; Lehane, M.; Braña Magdalena, A.; Furey, A. Detection of five new hydroxyl analogues of azaspiracids in shellfish using multiple tandem mass spectrometry. Toxicon, 2003, 41, 277-283.

(34) McCarron, P.; Kilcoyne, J.; Miles, C. O.; Hess, P. Formation of azaspiracids-3, -4, -6, and -9 via decarboxylation of carboxyazaspiracid metabolites from shellfish, J. Agric. Food Chem., 2009, 57, 160-169.

(35) Twiner, M. J.; El-Ladki, R.; Kilcoyne, J.; Doucette, G. J. Comparative effects of the marine algal toxins azaspiracid- $1,-2$, and -3 on Jurkat T lymphocyte cells, Chem. Res. Toxicol., 2012, $25,747-754$. 
Tables

Table 1. NMR Assignments for 4, 5 and $\mathbf{7 - 1 0}$ in $\mathrm{CD}_{3} \mathrm{OH}$

\begin{tabular}{|c|c|c|c|c|c|c|c|c|c|c|c|c|}
\hline \multirow{2}{*}{$\begin{array}{c}\text { Positio } \\
n\end{array}$} & \multicolumn{2}{|c|}{4} & \multicolumn{2}{|c|}{5} & \multicolumn{2}{|c|}{7} & \multicolumn{2}{|c|}{8} & \multicolumn{2}{|c|}{9} & \multicolumn{2}{|c|}{10} \\
\hline & ${ }^{13} \mathrm{C}$ & ${ }^{1} \mathrm{H}$ & ${ }^{13} \mathrm{C}$ & ${ }^{1} \mathrm{H}$ & ${ }^{13} \mathrm{C}$ & ${ }^{1} \mathrm{H}$ & ${ }^{13} \mathrm{C}$ & ${ }^{1} \mathrm{H}$ & ${ }^{13} \mathrm{C}$ & ${ }^{1} \mathrm{H}$ & ${ }^{13} \mathrm{C}$ & ${ }^{1} \mathrm{H}$ \\
\hline 1 & $\begin{array}{c}179 . \\
9\end{array}$ & & $\begin{array}{c}181 . \\
7\end{array}$ & & $\begin{array}{c}179 . \\
7\end{array}$ & & $\begin{array}{c}181 . \\
6\end{array}$ & & $\begin{array}{c}179 . \\
9\end{array}$ & & $\begin{array}{c}181 . \\
5\end{array}$ & \\
\hline 2 & 45.3 & $\begin{array}{l}2.32 \\
2.36\end{array}$ & 38.5 & $\begin{array}{l}2.23, \\
2.23\end{array}$ & 45.3 & $\begin{array}{l}2.32 \\
2.36\end{array}$ & 38.5 & $\begin{array}{l}2.23, \\
2.23\end{array}$ & 45.2 & $\begin{array}{l}2.32 \\
2.36\end{array}$ & 38.6 & $\begin{array}{l}2.22, \\
2.22\end{array}$ \\
\hline 3 & 70.4 & 4.42 & 30.4 & $\begin{array}{l}2.32, \\
2.32\end{array}$ & 70.5 & 4.43 & 30.4 & $\begin{array}{l}2.33, \\
2.33\end{array}$ & 70.5 & 4.42 & 30.4 & $\begin{array}{l}2.32, \\
2.32\end{array}$ \\
\hline 4 & $\begin{array}{c}135 . \\
0\end{array}$ & 5.77 & $\begin{array}{c}133 . \\
9\end{array}$ & 5.75 & $\begin{array}{c}135 . \\
0\end{array}$ & 5.77 & $\begin{array}{c}133 . \\
9\end{array}$ & 5.75 & $\begin{array}{c}134 . \\
7\end{array}$ & 5.75 & $\begin{array}{c}133 . \\
6\end{array}$ & 5.72 \\
\hline 5 & $\begin{array}{c}130 . \\
5\end{array}$ & 5.67 & $\begin{array}{c}130 . \\
6\end{array}$ & 5.43 & $\begin{array}{c}130 . \\
5\end{array}$ & 5.68 & $\begin{array}{c}130 . \\
6\end{array}$ & 5.43 & $\begin{array}{c}131 . \\
0\end{array}$ & 5.65 & $\begin{array}{c}131 . \\
0\end{array}$ & 5.40 \\
\hline 6 & 71.8 & 4.86 & 72.5 & 4.79 & 71.8 & 4.86 & 72.5 & 4.79 & 72.0 & 4.79 & 72.7 & 4.72 \\
\hline 7 & $\begin{array}{c}129 . \\
0\end{array}$ & 5.67 & $\begin{array}{c}129 . \\
4\end{array}$ & 5.64 & $\begin{array}{c}129 . \\
0\end{array}$ & 5.66 & $\begin{array}{c}129 . \\
5\end{array}$ & 5.64 & $\begin{array}{c}122 . \\
6\end{array}$ & 5.37 & $\begin{array}{c}123 . \\
1\end{array}$ & 5.34 \\
\hline 8 & $\begin{array}{c}123 . \\
4\end{array}$ & 5.74 & $\begin{array}{c}123 . \\
2\end{array}$ & 5.73 & $\begin{array}{c}123 . \\
4\end{array}$ & 5.74 & $\begin{array}{c}123 . \\
2\end{array}$ & 5.72 & $\begin{array}{c}131 . \\
2\end{array}$ & & $\begin{array}{c}131 . \\
0\end{array}$ & \\
\hline 9 & 35.8 & $\begin{array}{l}2.12 \\
2.48 \\
\end{array}$ & 35.7 & $\begin{array}{l}2.11, \\
2.47\end{array}$ & 35.8 & $\begin{array}{l}2.13, \\
2.48\end{array}$ & 35.7 & $\begin{array}{l}2.12 \\
2.48 \\
\end{array}$ & 40.4 & $\begin{array}{l}1.98, \\
2.42\end{array}$ & 40.4 & $\begin{array}{l}1.96, \\
2.42\end{array}$ \\
\hline 10 & $\begin{array}{c}107 . \\
1\end{array}$ & & $\begin{array}{c}107 . \\
2\end{array}$ & & $\begin{array}{c}107 . \\
1\end{array}$ & & $\begin{array}{c}107 . \\
2\end{array}$ & & $\begin{array}{c}107 . \\
4\end{array}$ & & $\begin{array}{c}107 . \\
4\end{array}$ & \\
\hline 11 & 33.2 & $\begin{array}{l}1.65, \\
2.31\end{array}$ & 33.2 & $\begin{array}{l}1.63, \\
2.32\end{array}$ & 33.2 & $\begin{array}{l}1.65, \\
2.31\end{array}$ & 33.2 & $\begin{array}{l}1.64, \\
2.33\end{array}$ & 33.3 & $\begin{array}{l}1.64, \\
2.32\end{array}$ & 33.3 & $\begin{array}{l}1.63, \\
2.32\end{array}$ \\
\hline 12 & 37.6 & $\begin{array}{l}1.96, \\
2.15\end{array}$ & 37.5 & $\begin{array}{l}1.95 \\
2.13\end{array}$ & 37.6 & $\begin{array}{l}1.96, \\
2.15\end{array}$ & 37.5 & $\begin{array}{l}1.96, \\
2.13\end{array}$ & 37.5 & $\begin{array}{l}1.97 \\
2.16 \\
\end{array}$ & 37.4 & $\begin{array}{l}1.96, \\
2.15\end{array}$ \\
\hline 13 & $\begin{array}{c}111 . \\
3\end{array}$ & & $\begin{array}{c}111 . \\
3\end{array}$ & & $\begin{array}{c}111 . \\
3\end{array}$ & & $\begin{array}{c}111 . \\
3\end{array}$ & & $\begin{array}{c}111 . \\
2\end{array}$ & & $\begin{array}{c}111 . \\
2\end{array}$ & \\
\hline 14 & 30.9 & 2.01 & 31.0 & 2.00 & 30.9 & 2.03 & 31.0 & 2.01 & 31.0 & 2.00 & 31.0 & 1.99 \\
\hline 15 & 32.7 & $\begin{array}{l}1.74, \\
1.83\end{array}$ & 32.6 & $\begin{array}{l}1.75 \\
1.83 \\
\end{array}$ & 32.7 & $\begin{array}{l}1.75, \\
1.83 \\
\end{array}$ & 32.6 & $\begin{array}{l}1.76 \\
1.83 \\
\end{array}$ & 32.7 & $\begin{array}{c}1.73 \\
1.82 \\
\end{array}$ & 32.6 & $\begin{array}{l}1.73 \\
1.82 \\
\end{array}$ \\
\hline 16 & 77.9 & 3.92 & 78.0 & 3.90 & 78.0 & 3.90 & 78.2 & 3.89 & 77.9 & 3.91 & 78.0 & 3.90 \\
\hline 17 & 73.3 & 4.18 & 73.1 & 4.20 & 73.1 & 4.19 & 73.2 & 4.22 & 73.1 & 4.16 & 73.1 & 4.17 \\
\hline 18 & 38.4 & $\begin{array}{l}1.99, \\
2.06\end{array}$ & 38.2 & $\begin{array}{l}2.00, \\
2.00\end{array}$ & 38.7 & $\begin{array}{l}2.00, \\
2.04\end{array}$ & 37.9 & $\begin{array}{l}2.00, \\
2.00\end{array}$ & 38.4 & $\begin{array}{l}2.00 \\
2.06\end{array}$ & 38.2 & $\begin{array}{l}2.01, \\
2.01\end{array}$ \\
\hline 19 & 79.8 & 4.41 & 79.4 & 4.38 & 79.3 & 4.41 & 78.9 & 4.38 & 79.6 & 4.41 & 79.3 & 4.38 \\
\hline 20 & 80.2 & 3.29 & 79.3 & 3.49 & 77.3 & 3.48 & 76.7 & 3.77 & 80.2 & 3.30 & 79.4 & 3.50 \\
\hline 21 & 97.9 & & 99.5 & & 99.8 & & $\begin{array}{c}102 . \\
2\end{array}$ & & 97.8 & & 99.5 & \\
\hline 22 & 31.9 & $\begin{array}{l}1.51, \\
2.11\end{array}$ & 38.5 & $\begin{array}{l}1.80, \\
2.29\end{array}$ & 36.1 & 2.28 & 40.0 & 2.18 & 31.9 & $\begin{array}{l}1.51, \\
2.11\end{array}$ & 38.5 & $\begin{array}{l}1.80, \\
2.28\end{array}$ \\
\hline 23 & 29.4 & $\begin{array}{l}1.58, \\
1.62\end{array}$ & 71.1 & 3.93 & 38.7 & $\begin{array}{l}1.41 \\
1.41\end{array}$ & 76.5 & 3.60 & 29.4 & $\begin{array}{l}1.58, \\
1.62 \\
\end{array}$ & 71.1 & 3.93 \\
\hline 24 & 39.5 & 1.33 & 44.5 & 1.48 & 42.0 & 1.36 & 46.7 & 1.49 & 39.5 & 1.33 & 44.5 & 1.48 \\
\hline 25 & 80.6 & 3.96 & 74.1 & 4.35 & 79.7 & 3.92 & 73.6 & 4.33 & 80.5 & 3.96 & 74.1 & 4.36 \\
\hline 26 & $\begin{array}{c}147 . \\
2\end{array}$ & & $\begin{array}{c}147 . \\
6\end{array}$ & & $\begin{array}{c}148 . \\
0\end{array}$ & & $\begin{array}{c}148 . \\
0\end{array}$ & & $\begin{array}{c}147 . \\
1\end{array}$ & & $\begin{array}{c}147 . \\
5\end{array}$ & \\
\hline 27 & 48.5 & $\begin{array}{l}2.17, \\
2.36 \\
\end{array}$ & 48.9 & $\begin{array}{l}2.23, \\
2.42 \\
\end{array}$ & 49.3 & $\begin{array}{l}2.15, \\
2.35 \\
\end{array}$ & 49.3 & $\begin{array}{l}2.24, \\
2.43 \\
\end{array}$ & 48.5 & $\begin{array}{l}2.17 \\
2.36 \\
\end{array}$ & 48.9 & $\begin{array}{l}2.23, \\
2.42 \\
\end{array}$ \\
\hline
\end{tabular}




\begin{tabular}{|c|c|c|c|c|c|c|c|c|c|c|c|c|}
\hline 28 & 98.0 & & 98.5 & & 98.0 & & 98.6 & & 98.1 & & 98.5 & \\
\hline 29 & 44.3 & $\begin{array}{l}1.33 \\
1.98\end{array}$ & 44.2 & $\begin{array}{l}1.37 \\
2.05\end{array}$ & 44.8 & $\begin{array}{l}1.30 \\
1.97\end{array}$ & 44.3 & $\begin{array}{l}1.36 \\
2.06\end{array}$ & 44.4 & $\begin{array}{l}1.33 \\
1.98\end{array}$ & 44.2 & $\begin{array}{l}1.37 \\
2.05\end{array}$ \\
\hline 30 & 26.7 & 2.24 & 26.5 & 2.25 & 26.7 & 2.24 & 26.4 & 2.24 & 26.7 & 2.25 & 26.5 & 2.25 \\
\hline 31 & 35.8 & $\begin{array}{l}1.48, \\
1.77\end{array}$ & 35.5 & $\begin{array}{l}1.52 \\
1.82\end{array}$ & 35.9 & $\begin{array}{l}1.47 \\
1.77\end{array}$ & 35.4 & $\begin{array}{l}1.52 \\
1.83\end{array}$ & 35.8 & $\begin{array}{l}1.48 \\
1.78\end{array}$ & 35.5 & $\begin{array}{l}1.51 \\
1.81\end{array}$ \\
\hline 32 & 72.7 & 4.24 & 72.8 & 4.33 & 72.9 & 4.23 & 72.9 & 4.35 & 72.7 & 4.24 & 72.8 & 4.33 \\
\hline 33 & 79.3 & 3.72 & $\mathrm{ND}^{*}$ & 3.93 & 79.4 & 3.72 & 81.2 & 4.01 & 79.4 & 3.72 & 79.7 & 3.93 \\
\hline 34 & 75.6 & 4.80 & 75.2 & 4.94 & 75.5 & 4.79 & 75.0 & 4.99 & 75.6 & 4.80 & 75.2 & 4.94 \\
\hline 35 & 43.1 & $\begin{array}{l}1.90 \\
2.38\end{array}$ & 42.1 & $\begin{array}{l}2.29, \\
2.52\end{array}$ & 43.0 & $\begin{array}{l}1.90 \\
2.38\end{array}$ & 41.8 & $\begin{array}{c}2.42 \\
2.56\end{array}$ & 43.1 & $\begin{array}{l}1.90 \\
2.39\end{array}$ & 42.1 & $\begin{array}{l}2.11, \\
2.52\end{array}$ \\
\hline 36 & 95.9 & & 96.4 & & 96.0 & & 96.5 & & 95.9 & & 96.4 & \\
\hline 37 & 37.9 & 1.74 & $\mathrm{ND}^{*}$ & 1.88 & 37.7 & 1.74 & 36.0 & 1.93 & 37.9 & 1.75 & 36.5 & 1.88 \\
\hline 38 & 40.0 & $\begin{array}{l}1.14, \\
1.54\end{array}$ & 38.2 & $\begin{array}{l}1.24 \\
1.63\end{array}$ & 39.9 & $\begin{array}{l}1.14, \\
1.53\end{array}$ & 38.0 & $\begin{array}{l}1.27 \\
1.65\end{array}$ & 40.0 & $\begin{array}{l}1.14, \\
1.54\end{array}$ & 38.6 & $\begin{array}{l}1.24, \\
1.63\end{array}$ \\
\hline 39 & 1.7 & 1.66 & $\mathrm{ID}^{*}$ & 1.83 & 31.8 & 1.65 & 29.6 & 1.88 & 31.7 & 1.66 & 30.3 & 1.83 \\
\hline 40 & 47.8 & $\begin{array}{l}2.51 \\
2.57\end{array}$ & 46.2 & $\begin{array}{l}2.74, \\
2.74\end{array}$ & 47.5 & $\begin{array}{l}2.48, \\
2.52\end{array}$ & 46.3 & $\begin{array}{l}2.77 \\
2.82\end{array}$ & 47.8 & $\begin{array}{l}2.51 \\
2.57\end{array}$ & 46.3 & $\begin{array}{l}2.74, \\
2.74\end{array}$ \\
\hline 14 & 16.7 & $\begin{array}{c}0.93 \\
8\end{array}$ & 16.6 & $\begin{array}{c}0.94 \\
1\end{array}$ & 16.7 & $\begin{array}{c}0.94 \\
2\end{array}$ & 16.6 & $\begin{array}{c}0.94 \\
4\end{array}$ & 16.7 & $\begin{array}{c}0.92 \\
7\end{array}$ & 16.6 & $\begin{array}{c}0.93 \\
0\end{array}$ \\
\hline 22-Me & & & & & 16.5 & $\begin{array}{c}0.89 \\
0\end{array}$ & 13.7 & $\begin{array}{c}1.09 \\
7\end{array}$ & & & & \\
\hline 24-Me & 18.2 & $\begin{array}{c}0.81 \\
9\end{array}$ & 14.7 & $\begin{array}{c}0.91 \\
8\end{array}$ & 18.1 & $\begin{array}{c}0.81 \\
3\end{array}$ & 14.9 & $\begin{array}{c}0.92 \\
4\end{array}$ & 18.2 & $\begin{array}{c}0.81 \\
8\end{array}$ & 14.7 & $\begin{array}{c}0.91 \\
7\end{array}$ \\
\hline $\begin{array}{c}26=\mathrm{CH} \\
2\end{array}$ & $\begin{array}{c}116 . \\
1 \\
\end{array}$ & $\begin{array}{l}5.14, \\
5.22 \\
\end{array}$ & $\begin{array}{c}117 . \\
1 \\
\end{array}$ & $\begin{array}{l}5.21, \\
5.35\end{array}$ & $\begin{array}{c}115 . \\
3 \\
\end{array}$ & $\begin{array}{l}5.09, \\
5.25 \\
\end{array}$ & $\begin{array}{c}117 . \\
1 \\
\end{array}$ & $\begin{array}{l}5.20, \\
5.39 \\
\end{array}$ & $\begin{array}{c}116 . \\
1 \\
\end{array}$ & $\begin{array}{l}5.14, \\
5.23 \\
\end{array}$ & $\begin{array}{c}117 . \\
0\end{array}$ & $\begin{array}{l}5.21, \\
5.35\end{array}$ \\
\hline 30-Me & 23.9 & $\begin{array}{c}0.92 \\
8\end{array}$ & 23.6 & $\begin{array}{c}0.95 \\
2\end{array}$ & 23.8 & $\begin{array}{c}0.92 \\
9\end{array}$ & 23.5 & $\begin{array}{c}0.95 \\
8\end{array}$ & 23.9 & $\begin{array}{c}0.92 \\
9\end{array}$ & 23.7 & $\begin{array}{c}0.95 \\
1\end{array}$ \\
\hline 37-Me & 16.1 & $\begin{array}{c}0.86 \\
0\end{array}$ & 15.7 & $\begin{array}{c}0.92 \\
9\end{array}$ & 16.1 & $\begin{array}{c}0.85 \\
5\end{array}$ & 15.5 & $\begin{array}{c}0.95 \\
2\end{array}$ & 16.1 & $\begin{array}{c}0.86 \\
0\end{array}$ & 15.7 & $\begin{array}{c}0.92 \\
7\end{array}$ \\
\hline 39-Me & 19.5 & $\begin{array}{c}0.85 \\
5\end{array}$ & 18.9 & $\begin{array}{c}0.92 \\
1\end{array}$ & 19.4 & $\begin{array}{c}0.85 \\
0\end{array}$ & 18.7 & $\begin{array}{c}0.94 \\
0\end{array}$ & 19.5 & $\begin{array}{c}0.86 \\
2\end{array}$ & 18.9 & $\begin{array}{c}0.92 \\
2\end{array}$ \\
\hline 8-Me & & & & & & & & & 23.0 & 1.70 & 23.0 & 1.69 \\
\hline
\end{tabular}

${ }^{*}$ Not detected due to limited signal-to-noise 
Table 2. Relative (to 1) Molar Responses of 4-10 by LC-MS(MS) under Acidic Conditions

\begin{tabular}{|c|c|c|c|c|c|c|c|c|}
\hline AZA & \multicolumn{2}{|c|}{ SIM } & \multicolumn{3}{c|}{ SRM isocratic } & \multicolumn{3}{c|}{ SRM gradient } \\
\cline { 2 - 9 } & isocratic $^{\mathrm{a}}$ & gradient $^{\mathrm{b}}$ & $\begin{array}{l}\mathrm{H}_{2} \mathrm{O} \\
\text { loss }\end{array}$ & $\mathrm{RDA}$ & $\begin{array}{c}\mathrm{m} / \mathrm{z} \\
362\end{array}$ & $\begin{array}{l}\mathrm{H}_{2} \mathrm{O} \\
\text { loss }\end{array}$ & $\mathrm{RDA}$ & $\begin{array}{c}\mathrm{m} / \mathrm{z} \\
362\end{array}$ \\
\hline $\mathbf{4}$ & 0.88 & 0.75 & 0.80 & 0.81 & 0.86 & 0.96 & 0.96 & 1.03 \\
\hline $\mathbf{5}$ & 0.77 & 0.70 & 0.55 & 0.47 & 0.47 & 0.61 & 0.54 & 0.53 \\
\hline $\mathbf{6}$ & 0.95 & 0.93 & 1.06 & 1.21 & 1.17 & 1.05 & 1.21 & 1.13 \\
\hline $\mathbf{7}$ & 0.45 & 0.40 & 0.37 & 0.33 & 0.37 & 0.40 & 0.37 & 0.40 \\
\hline $\mathbf{8}$ & 0.84 & 0.81 & 0.58 & 0.41 & 0.47 & 0.59 & 0.47 & 0.51 \\
\hline $\mathbf{9}$ & 0.53 & 0.49 & 0.45 & 0.48 & 0.61 & 0.50 & 0.53 & 0.68 \\
\hline $\mathbf{1 0}$ & 0.49 & 0.48 & 0.34 & 0.33 & 0.35 & 0.34 & 0.35 & 0.36 \\
\hline
\end{tabular}

${ }^{\mathrm{a}}$ Method C (i), ${ }^{\mathrm{b}}$ Method C (ii).

Table 3. Calculated $E_{50}$ Values and Relative Potencies for AZA Analogues Based on $T$ Lymphocyte Cytotoxicity

\begin{tabular}{|c|c|c|c|c|c|c|c|c|}
\hline \multirow[b]{2}{*}{ AZA } & \multicolumn{2}{|c|}{$24 \mathrm{~h}$} & \multicolumn{2}{|c|}{$48 \mathrm{~h}$} & \multicolumn{2}{|c|}{$72 \mathrm{~h}$} & \multirow{2}{*}{$\begin{array}{l}\text { Mean } \\
\mathrm{EC}_{50} \\
(\mathrm{nM})\end{array}$} & \multirow{2}{*}{$\begin{array}{c}\text { Relative } \\
\text { potency to } \\
\mathrm{AZA} 1^{\mathrm{b}}\end{array}$} \\
\hline & $\begin{array}{l}E_{50} \\
(n M)\end{array}$ & $95 \% \mathrm{Cl}$ & $\begin{array}{l}E_{50} \\
(n M)\end{array}$ & $95 \% \mathrm{Cl}$ & $\begin{array}{l}E_{50} \\
(n M)\end{array}$ & $95 \% \mathrm{Cl}^{\mathrm{a}}$ & & \\
\hline 4 & 2.1 & $0.3-15$ & 2.1 & $1.0-4.4$ & 1.9 & $1.0-3.5$ & 2.0 & 0.6 \\
\hline 5 & 2.7 & $0.5-15$ & 3.4 & $1.7-6.9$ & 2.8 & $1.6-4.7$ & 3.0 & 0.4 \\
\hline 6 & 0.1 & $0.03-0.4$ & 0.2 & $0.1-0.4$ & 0.2 & $0.1-0.5$ & 0.2 & 7.0 \\
\hline 8 & 0.3 & $0.1-1.2$ & 0.3 & $0.1-0.5$ & 0.2 & $0.1-0.4$ & 0.3 & 4.5 \\
\hline 9 & 2.2 & $0.7-7.4$ & 1.7 & $1.0-3.0$ & 1.7 & $1.1-2.6$ & 1.9 & 0.4 \\
\hline 10 & 2.9 & $1.2-6.8$ & 3.2 & $2.1-4.8$ & 3.1 & $1.8-5.5$ & 3.1 & 0.2 \\
\hline
\end{tabular}

${ }^{\mathrm{a} C}$ Confidence interval. ${ }^{\mathrm{b}}$ Comparisons between analogues should be done cautiously as data were collected from different experiments during which minor changes in in vitro AZA1 potency were observed. Relative potency values for AZA4, $-5,-6$, and -8 were compared to AZA1 $\mathrm{EC}_{50}$ values of $0.96,1.1$, and 1.3 for 24,48 , and $72 \mathrm{~h}$. Relative potency values for AZA9 and -10 were compared to AZA1 $\mathrm{EC}_{50}$ values of $0.51,0.89$, and 0.88 for 24,48 , and $72 \mathrm{~h}$. 
Figure 1. Structures of 1-10, their protonated masses and origin. The $\mathrm{m} / \mathrm{z}$ values of the fragments are for 1; corresponding fragments were observed for 2-10.

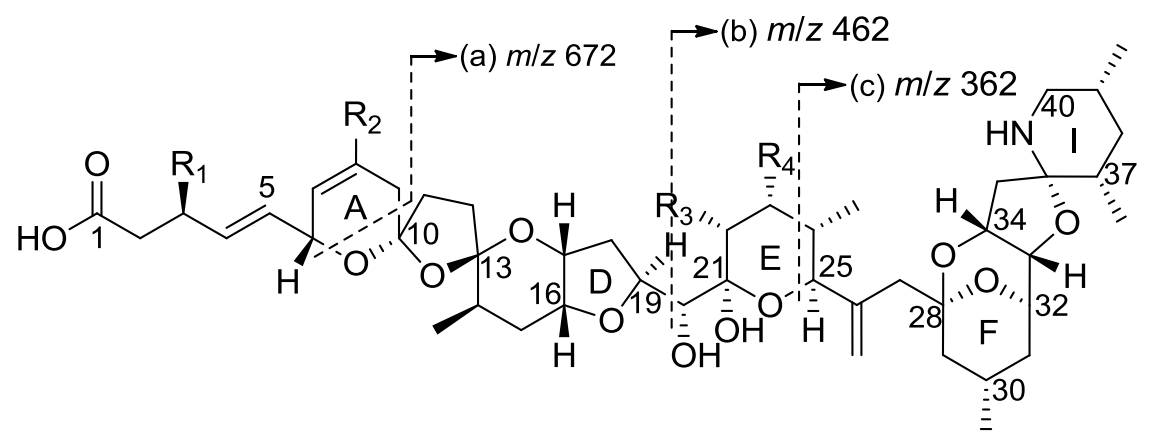

\begin{tabular}{cccccccc} 
& $\mathrm{R}_{1}$ & $\mathrm{R}_{2}$ & $\mathrm{R}_{3}$ & $\mathrm{R}_{4}$ & {$[\mathrm{M}+\mathrm{H}]^{+}$} & & \\
& $(\mathrm{C}-3)$ & $(\mathrm{C}-8)$ & $(\mathrm{C}-22)$ & $(\mathrm{C}-23)$ & $m / z$ & Origin & Status \\
\hline AZA1 (1) & $\mathrm{H}$ & $\mathrm{H}$ & $\mathrm{CH}_{3}$ & $\mathrm{H}$ & 842.5 & A. spinosum & phycotoxin \\
AZA2 (2) & $\mathrm{H}$ & $\mathrm{CH}_{3}$ & $\mathrm{CH}_{3}$ & $\mathrm{H}$ & 856.5 & A. spinosum & phycotoxin \\
AZA3 (3) & $\mathrm{H}$ & $\mathrm{H}$ & $\mathrm{H}$ & $\mathrm{H}$ & 828.5 & shellfish & metabolite \\
AZA4 (4) & $\mathrm{OH}$ & $\mathrm{H}$ & $\mathrm{H}$ & $\mathrm{H}$ & 844.5 & shellfish & metabolite \\
AZA5 (5) & $\mathrm{H}$ & $\mathrm{H}$ & $\mathrm{H}$ & $\mathrm{OH}$ & 844.5 & shellfish & metabolite \\
AZA6 (6) & $\mathrm{H}$ & $\mathrm{CH}$ & $\mathrm{H}$ & $\mathrm{H}$ & 842.5 & shellfish & metabolite \\
AZA7 (7) & $\mathrm{OH}$ & $\mathrm{H}$ & $\mathrm{CH}$ & $\mathrm{H}$ & 858.5 & shellfish & metabolite \\
AZA8 (8) & $\mathrm{H}$ & $\mathrm{H}$ & $\mathrm{CH}$ & $\mathrm{OH}$ & 858.5 & shellfish & metabolite \\
AZA9 (9) & $\mathrm{OH}$ & $\mathrm{CH}_{3}$ & $\mathrm{H}$ & $\mathrm{H}$ & 858.5 & shellfish & metabolite \\
AZA10 (10) & $\mathrm{H}$ & $\mathrm{CH}_{3}$ & $\mathrm{H}$ & $\mathrm{OH}$ & 858.5 & shellfish & metabolite \\
\hline
\end{tabular}


Figure 2. Structures for the E-rings of $\mathbf{5}$ and $\mathbf{8}$, showing dispositions of substituents. Observed ${ }^{1} \mathrm{H}-{ }^{1} \mathrm{H}$ coupling constants, and correlations (arrows) observed in the ROESY NMR spectra, are also shown.

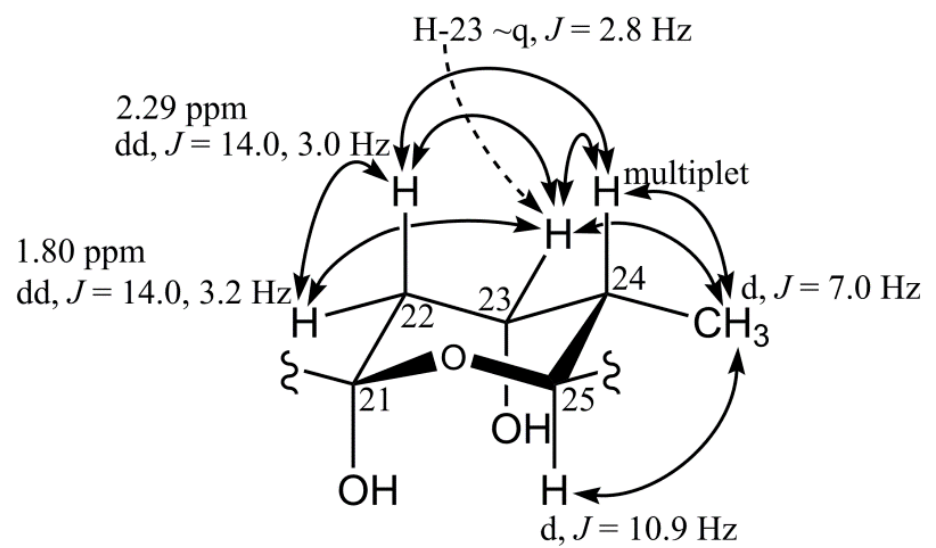

Azaspiracid-5 (5)

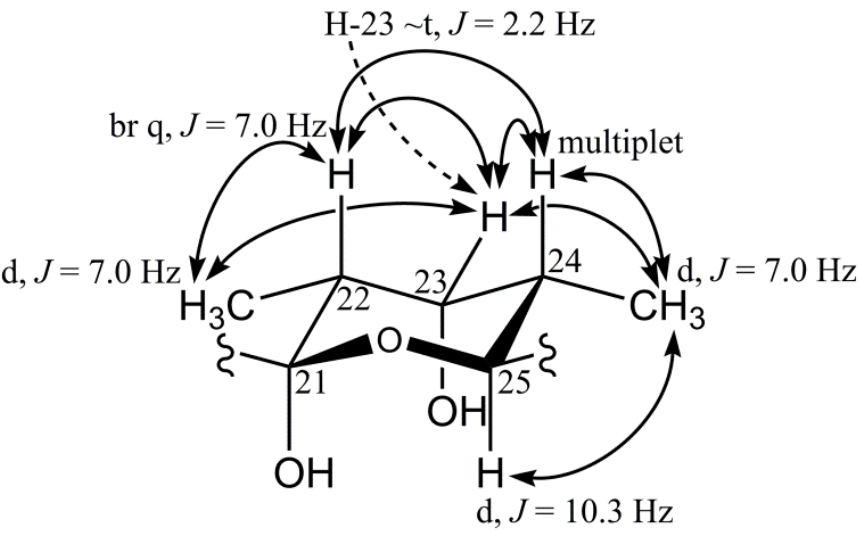

Azaspiracid-8 (8) 
Figure 3. Products detected by LC-MS after periodate cleavage of purified specimens on 1-10, and their calculated $\mathrm{m} / \mathrm{z}$ values.

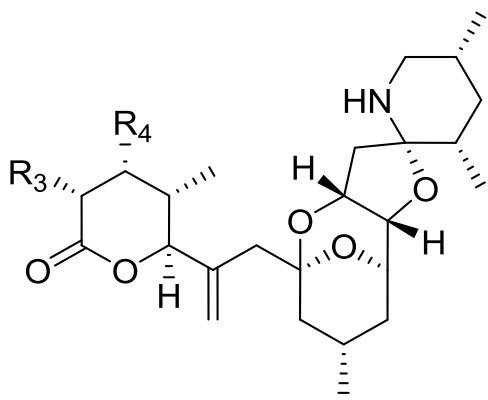

\begin{tabular}{|c|c|c|c|}
\hline Precursor & $\mathrm{R}_{3}$ & $\mathrm{R}_{4}$ & $\mathrm{~m} / \mathrm{z}[\mathrm{MH}]^{+}$ \\
\hline $1,2,7$ & $\overline{\mathrm{CH}_{3}}$ & $\mathrm{H}$ & 448.3 \\
\hline $3,4,6,9$ & $\mathrm{H}$ & $\mathrm{H}$ & 434.3 \\
\hline 5,10 & $\mathrm{H}$ & $\mathrm{OH}$ & 450.3 \\
\hline 8 & $\mathrm{CH}_{3}$ & $\mathrm{OH}$ & 464.3 \\
\hline
\end{tabular}


Figure 4. LC-MS/MS analysis (method $C$ ) of reference standards prepared for 1-10 under A) gradient and B) isocratic conditions. Note: two combined reference standards were prepared as indicated by the colours (blue, black).
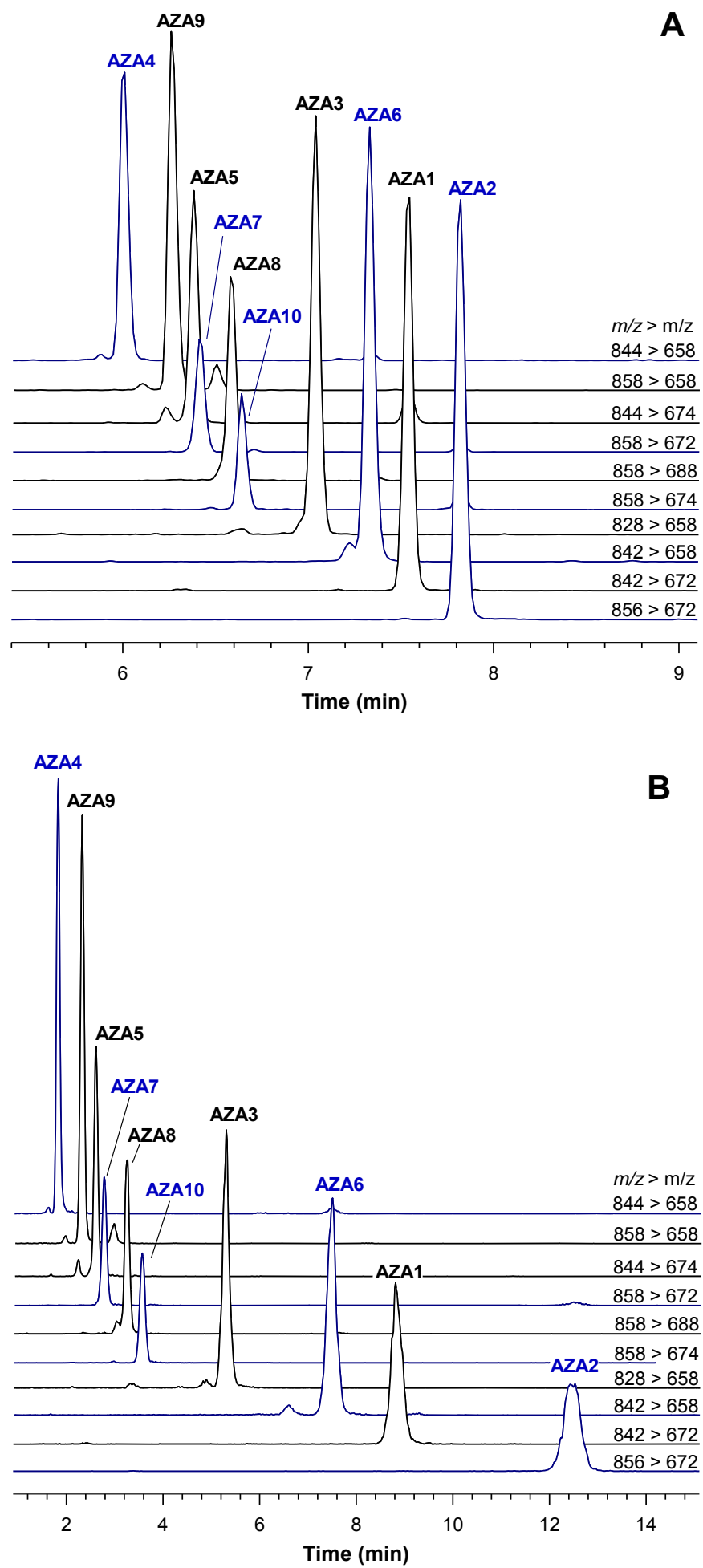
Figure 5. Effect of various AZA analogues on T lymphocyte cell viability. Jurkat $T$ cells were exposed to various concentrations of (A) 4, (B) 5, (C) 6, (D) 8, (E) 9 and (F) 10 for 24, 48, or $72 \mathrm{~h}$ and viability was assessed using the MTS assay. All data (mean \pm SE; $n=3-5)$ were normalized to the control $(10 \%$ $\mathrm{MeOH}$ vehicle).

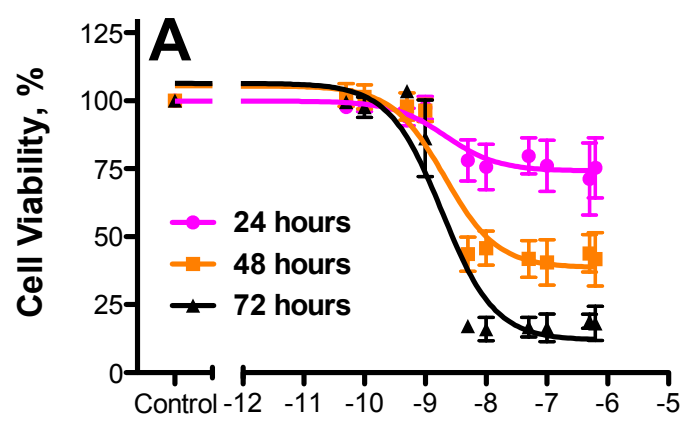

AZA4 concentration ( $\log M)$

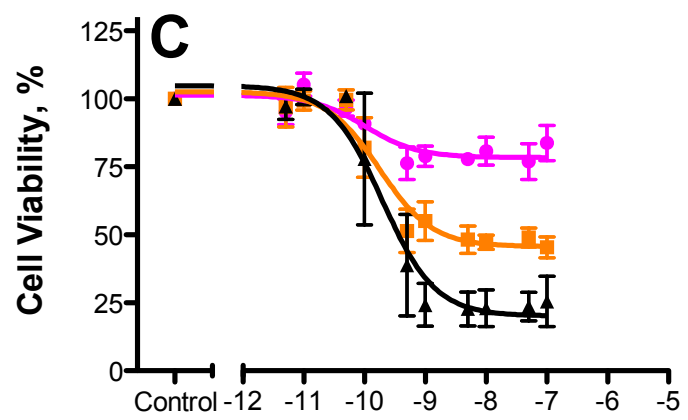

AZA6 concentration ( $\log M$ )

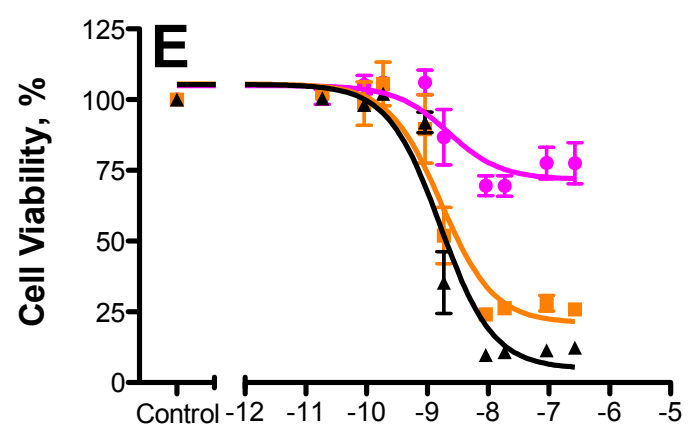

AZA9 concentration ( $\log M)$

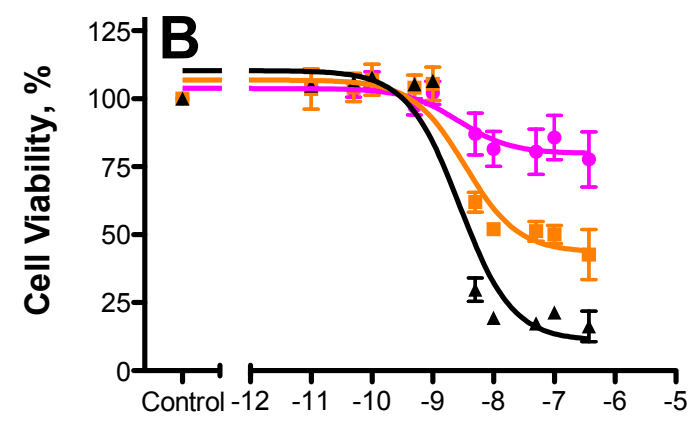

AZA5 concentration ( $\log M)$

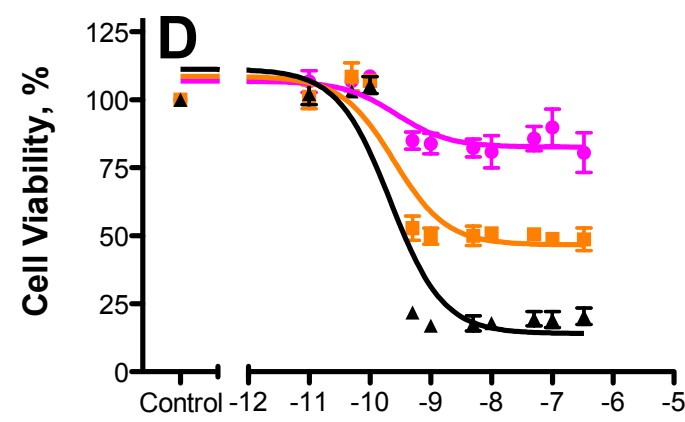

AZA8 concentration ( $\log M)$

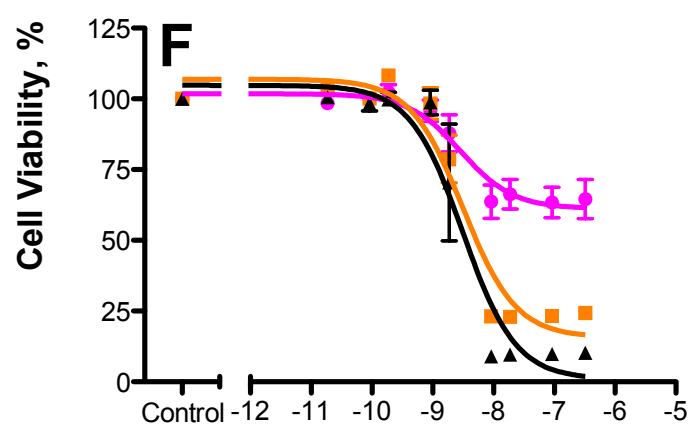

AZA10 concentration ( $\log M)$ 